\title{
A Philosophical Appraisal of John Rawls’ Difference Principle in the Context of the Quota System of Nigeria
}

\author{
Macaulay A. Kanu \\ Ebonyi State University
}

\begin{abstract}
The concept of justice is a complex phenomenon which has been subjected to various legal, social, and philosophical interpretations. In other words, for the concept to make meaning to analysts and various intellectual communities, it has to undergo a process of concept conceptualization and operationalisation. It is therefore this lack of univocal definition of justice that one can philosophically assert that there is no theory of justice but theories of justice. The purpose of this article is not to delve into the various analyses of theories, meanings, definitions, and/or explanations of justice but to examine John Rawls' Difference Principle of justice in the context of the Nigerian Quota System. In order to make this writing less nebulous and less ambiguous and more explicit and clear, I shall examine the definitions of the concepts of both justice and Quota System. In addition, evaluation of the philosophical and theoretical assumptions of the Rawls' theory and the Quota System will be made with a view to revealing their applicability and relevance in our real economic socio-political system (in Nigeria).
\end{abstract}

Keywords: justice, leadership, exploitation and citizens

\section{The Meaning of Justice}

Although the concept of justice means different things to different authorities and at different historical epochs, it is a fundamental moral concept. This is because it is the basic yardstick for judging human conducts or actions as right or wrong. Justice is a moral value or virtue for man's actions in the society. Concerning epochs, different meanings have been manifested. For instance, in Plato's Republic, Cephalus argues that justice means "saying the truth and paying one's debt." Of course philosophers disagree with this notion of justice for instance: Socrates dismisses that definition with illustrations. For Glenn of the contemporary period, justice is "the constant and perpetual will to render to everyone what is due for him" (1961, 222). While for B. O. Iluyomade and B. U. Eka, it refers to "an inherent right in man to have fair and just treatment at the hands of the rulers or their agents” $(1980,13)$.

The issue of justice presupposes the impartiality of norms. It helps to ensure that morality is not simply a means to clothe and advance self-interest. It is because of the propensity of human selfishness that philosophers emphasize the need for dispassion and disinterest. As a result, philosophers have argued that moral justice must be defined and applied in terms of perspectives and interests other than those of the actor. This emphasis is manifest in John Rawls' classic work: A Theory of Justice. Here, he argues that moral principles should be

Macaulay A. Kanu, Ph.D., Department of Philosophy and Religion, Faculty of Social Sciences and Humanities, Ebonyi State University, Nigeria; main research field: Philosophy of Science and Social and Political Philosophy. Email: mackandis2007@yahoo.com. 
based on impartiality by requiring that they should be selected through a "veil of ignorance," that is, defining and selecting norms without knowledge of who will benefit from them. It is in line with the spirit of fairness and just practice that I will examine Rawls' Difference Principle whose objective is minimization of the disadvantages of the people in the context of Quota System of Nigeria.

\section{The Meaning of Quota System}

Quota System has to do with the quest for relatively fair representation of the characteristics of the population of a given geographical entity. According to Henry Nicholas, Quota System refers to "the argument that traditional entry and promotion of qualifications of the civil service, such as high task scores, should be reduced or waved for the disadvantaged until the number of women and minority groups members working in government at all ranks at least equals to their proportion of the population at large” $(1980,269)$. In case of Nigeria, it is a strategy, process, and/or system through which the disadvantaged populations such as the minority ethnic groups and educationally backwards areas are given consideration in respect of appointments and positions within the federal set-up with a view to avoiding domination and exploitation by the advantaged population and to giving a sense of belonging to all the heterogeneous entities. This social concept has been given a legal and constitutional backing in the respective republics of Nigeria including the present republican constitution.

\section{Philosophical Assumptions of Rawls' Difference Theory}

The epistemological foundation of Rawls' theory of justice could be traced to the socio-political philosophy of "social contract” which dominates the works of authorities like Hobbes, John Locke, Rousseau, to mention but just a few on the origin of the state. The major conceptual perspective of Rawls is that the principles of justice which is to be the foundation of society are the results of an agreement in what he calls "the original position" or a social contract theory. In his A Theory of Justice, he maintains that the original position is "the appropriate initial status quo which ensures that the fundamental agreements reached in it are fair." This fact manifests the legacy "justice as fairness" (Rawls 1971, 47). Contrary to other social contract, theorists who seem to have believed that their theories portray an actual historical situation, Rawls merely constructs an imaginary or a hypothetical social contract which assumes that all human beings are due equal respect. Rawls portrays the original position as the position of natural equality of men to all advantages and burdens arising from their social cooperation. The main and essential feature of Rawls' picture of the original position is that equal human beings choose their principles of justice behind "a veil of ignorance."

On explaining how the agreement could be reached without preferences, affections, sentiments, malice, prejudice, and/or bias so as to arrive at a fair and objective condition, Rawls argues that it is imperative to step behind a "Veil of ignorance" which simply means what none of us knows (that is, we act as though we do not know) what our special circumstances are. The veil of ignorance ensures that no one tailors principles to his own advantage. The agreement arrived at by the parties is free and fair. That is called justice.

Another fundamental assumption is that all men have a sense of justice. Although he agrees that there is no unanimity in terms of the definition of justice, he argues that all rational human beings have a way of understanding what is fair and what is not fair. For him, reasonable and sound men know "that it is not fair to achieve the good life for someone at the expenses of others” (Stumpf \& Abel 2002, 510). This theory of justice presupposes that the parties (citizens) are bound by duty and obligation. 
Sometime in a press conference titled "Rediscovering Nigeria," a front line politician of the then Cross River State and Calabar based communication consultant, Etubom Bassey Ekpo Bassey commenting on the constitutional conference asserts that "the conference shall be a success, if it is able to focus sufficiently on the inequities of the Nigerian system particularly the appalling unequal exchanges between east and the rest of Nigeria” (Bassey 1994, 4).

It is as a result of the inadequacy of the Nigerian type of Quota System that the unity and corporate existence of Nigeria is in crisis. The philosophy of Quota System has been defeated. This is evident in the statement of a Calabar High Chief: "I stand for a United Nigeria, but a Nigeria based on justice” (Bassey 1994, 4). The Nigerian federation will continue to generate antagonistic and hostile agitations until there is an arrangement that can narrow the wide gap of socio-economic inequalities and alienation. This view is supported by the position of Etubom Bassey Ekpo Bassey. For this achievement, the legislative sitting must also address our despicable social situation and provide a basis for reducing the differences in terms of trade between the social classes.

In his philosophical analysis of the concept of justice from "original position" that is the Hobbisan state of nature and the "veil of ignorance," Rawls develops two principles of justice. According to him, "in the first principle, each person is assumed to have an equal right to the most extensive basic liberty compatible with a similar liberty for others." This of course is the equal distribution of liberty principle called "Human Rights." Human Rights are rights which do not depend on man to make laws but are rights irrespective of whether or not the state guarantees them. This liberty principle refers to social and political freedoms which are reflected in the various charters on Human Rights, the Universal Declaration of Human Rights as well as the fundamental rights enshrined in modern constitutions. This includes freedom of expression, the right to vote and be voted for, freedom of conscience, freedom to hold property, and other political liberties. Along this reasoning, it should be stressed that the fundamental Human Rights are the chief sources of any people oriented constitution. As such ought to be the case, Human Rights thus impose a duty on the state and its agencies as well as the individuals to ensure their protection and promotion. Apparently as democratic principles are portrayed theoretically, it is believed that democratic practice is our best chance of establishing humanity's avowed harmonious society and guaranteed better living. But the contrary is the case in Nigeria in spite of the advantage of Quota System as enshrined in the acclaimed constitution.

The second principle of justice wherein falls the difference principle has to do with hard fact of our socio-economic circumstances. In this principle, Rawls recognizes certain inequalities among people. People's differences are reflected in the distribution of wealth and income. People are endowed with different talents: Some are poor; some are rich; some are highly intelligent while others are not. For him, "social and economic inequalities are to be arranged so that they are both:

a. reasonably expected to be everyone's advantage and

b. attached to positions and offices open to all” (Stumpf \& Abel 2002, 511).

In this principle, Rawls is not calling for equal allocation of wealth and income; he articulates a situation where unequal division of resources among unequal human beings will lead to the betterment of everyone. This posits that it will be a violation of justice if a society sacrifices personal and political freedoms, the basic liberties, in exchange for some additional social benefits. In other words, his theory of justice in respect of the difference principle holds that "inequalities of wealth and authority are just only if they result in compensating benefits for everyone, and in particular for the least advantaged members of the society (Stumpf \& Abel 2002, 
512). This explanation and understanding of the difference principle are manifest as Rawls states: "Since the parties are assumed not to take interest in another's interest, their acceptance of these inequalities is only acceptance of justice... A person in the original position would therefore concede the justice of these inequalities” $(1971,151)$.

Rawls' theory of difference asserts that justice prevails when "all social values, liberty and opportunities, income and wealth, and the bases of self-respect are to be distributed equally unless an unequal distribution of any, or all of these values are to everyone's advantage" (Omoregbe 1994, 113).

The implication of this principle is that if any inequality will not enhance the opportunities of those with lesser opportunity only, then should it be shunned outright. If for example, an overbearing saving or tax is imposed on members of the society, this must serve to mitigate the burden of those undergoing hardship in the social structure. And this refers to the least favored segment of the society, the poor. Relating these inequalities to Nigerian social and economic structure, such should not be allowed to prevail. The political and economic programme of privatization and commercialization promotes inequalities to the detriment of the majority of the people, thereby subjecting the people to abject poverty and denial of their liberties.

But in consideration of the basic aims and objectives of the difference principle, Rawls believes that men are to be treated in the supposed basic structure in accordance with the principles to which they would consent under equality in the original position. That is to say, to regard persons as ends in themselves is to accept relinquishing those gains which do not contribute to their collective expectation.

\section{A Critical Evaluation of John Rawls' Difference Principle and Its Place in the Quota System of Nigeria}

From the assumption of John Rawls' Difference Principles, one can see the underlying justification of an arrangement of distribution which will lead to the benefit of the least advantaged in particular and the benefit of everybody in general. The essence of the Quota System is to help minimize the degree of antagonism, parochialism, acrimony, and hostility between the core groups and the peripheries, and among the major and minor heterogeneous entities that constitute a mere geographical expression called Nigeria. It is an incontrovertible fact that the Nigerian policy is characterized with high degree of social and economic inequalities, unequal citizenship, lack of even and equitable distribution of industrial facilities, and social services. The rectification of these denials has been the agitations by various ethnic groups such as that of Ogonis of River State under the umbrella of the Movement for the Survival of Ogoni People (MOSOP) led by Ken Saro-Wiwa. A front line nationalist and first republic politician, Anthony Enahoro in his time also calls for a constitutional conference to adequately address the plight of the minority ethnic groups in Nigeria. The Quota System is a formula and an institutional means of closing the gap of the differences and to reduce relative deprivation which could lead to a catastrophic crisis within the Federal set up. It is important to look at the fundamental objective of the Nigerian federation as declared in the preamble of our constitution. Thus:

To live in unity and harmony as one indivisible and indissoluble sovereign Nation... And to provide for a constitution for the purpose of promoting the good government and welfare of all persons in our country on principles of freedom, equality, and justice, and for purpose of consolidating the unity of our people... (Constitution of the Federal Republic of Nigeria 1999, 15).

If one looks at the above preamble, one will see the two principles of John Rawls in respect of justice. If we are to have unity, progress, harmony, and live as one indivisible and indissoluble sovereign nation, we must 
try to reduce the degree of imbalance, differences, inequalities, and/or relative deprivation, domination, and exploitation among members of our community and communities within the community. The arrangement or formula must be such that results must be positive, which is to the benefits of everyone and to the enhancement of the positions and benefits of the least advantaged as to be in line with the Difference Principle.

Despite the abuse of the Quota System in Nigeria, it is my considered view that the philosophical assumptions of the Quota System are in line with John Rawls' Difference Principle. This position is supported by Section 14, subsection 3 of the constitution which states that:

The composition of the government of the federation or any of its agencies and the conduct of its affairs shall be carried out in such manner as to reflect federal character of Nigeria and the need to promote national unity, and also to command national loyalty thereby ensuring that there shall be no predominance of persons from a few states or from a few ethnic or other sectional groups in that government or in any of its agencies. (Constitution of Federal Republic of Nigeria 1999, 26).

But to what extent has the Quota System promoted justice in respect of the first principle of John Rawls? Have the least disadvantaged people of Nigerian's standard of living been enhanced? Why are the various ethnic groups calling the National Assembly for resource allocation for the benefit of the masses? Have the poor masses benefitted from federal character instrument in Nigeria? Does the Quota System promote meritocracy, economic efficiency, and effectiveness?

As stated above philosophically, theoretically, and in orientation, Difference Principle and Quota System share a lot in common, but empirically and practically the Quota System has failed to promote justice which John Rawls' Difference Principle articulates: For instance, how have the poor masses of this country benefitted from the Quota System? The observation of this is that the standard of living has tremendously fallen. In terms of appointment, it is the elites as members of leadership cabal in the various communities that have capitalized upon that to hold positions with which they consolidate their power of exploitation and deprivation. I do not agree that there is justice in Nigeria where the rich becomes richer and the poor becomes poorer.

The so-called democracy in the present dispensation is a threat to humanity. It has used its position to enrich the elitist leadership class (the cabal) to the detriment of the masses. The leadership class in its quest and legal defense for the wide gaps between the rich and the poor has introduced certain economic policies like that of privatization and commercialization. The main objective of the policies is the promotion of self-interest against public or collective interest. Also, as the aim of the present, disguised form of democracy is profit-actualization without putting into consideration the functional objectives of producing and promoting the basic facilities for national development. The sources of Nigerian wealth are natural resources which are constitutionally justified as public or collective ownership. With the promotion of self-interest by the so-called capitalist democracy, the relevance of Quota System is ignored. Just the individuals in the leadership class are now in unjustified possession of national wealth which was previously under public ownership. Even leadership in Nigerian is no longer nationalistic rather it is a threat to the genuine development of the nation. The failure of John Rawls' Difference Principle in relation to Quota System application in Nigeria is manifest in the idiocy of the removal of petrol subsidy. The existence and implementation of the subsidy by the government in the past to some extents make movements and journeys for the masses especially in the economy, a breakthrough. The objective solution which the government gives for the removal of the subsidy has not manifested rather, it has worsened the denial of the principle of justice on the masses. The existence of the subsidy to some extent is a generalized form of benefit of the natural resource (petroleum) to the citizens. 
So far, there is no positive advantage of the removal to the people, rather it is a denial of justice in the distributive benefits of the natural gift to the people.

So far, Quota System has become a capitalist instrument for the generation of wealth and income for the agents of the western bourgeoisie. The system has generated more contradictions, bifurcations, cleavages, and patterns of antagonism and hostilities that the historical antecedents and/or dynamics are repeating themselves with its characteristic socio-political consequences of crisis of confidence, crisis of legitimacy, and crisis of participation. All these become the order of the day and as such there is fear of civil crisis and disintegration in Nigeria.

The Quota System and theory of difference assert that those who possess the authority and control the resources should recognize the incapacitated persons and make sure that these poor people benefit from their arrangement, but this is not the case in Nigeria. The Quota System of Nigeria also promotes mediocrity. The principle is opposed to merit system; it denies the best qualified persons for the jobs, the opportunities, and places and promotes unqualified persons. The logical outcomes are inefficiency and ineffectiveness within the system. Equal opportunity is denied the citizens. This position tallies with the view that Quota System considers candidate for admission not on their own academic merit but on the basis of the accident of their birth.

It is my position that unequal treatment of two citizens with equal credentials on the bases of place of birth or geo-graphical location is no justice because the deprivation might lead to the distortion and strangulation of talents, experience, skill, and professionalism that could generate the desired wealth and resources that will better the welfare of the entire nation. In other words, Rawls' second principle contradicts its first principle. According to D. D. Raphael, in his work Justice and liberty, "Rawls says that the first principle requires equality in the assignment of basic rights and duties... Later confining the first principle to liberty, which he regards as the most basic rights” $(1980,105)$.

Another disadvantage of the principle of Quota System as experienced in Nigeria with specific reference to admission into universities is that it leads to underutilization. Indeed some states may not be able to produce enough candidates with the minimum qualifications to cover their quota and thus some vacancies would remain unfilled while qualified Nigerians from other states are kept out. If one critically reflects on the composition of the Federal Legislative body and the Executive Counsel of the present 1999 Republic, one will see that some parts are marginalized and the minorities of most parts of the country have no representation at all.

The oil producing areas are crying over the denial of much of their resources and the environmental hazards of which they pass through. According to Dr. G. B. Leton, the then president, Movement for the Survival of Ogoni People (MOSOP), petroleum was discovered in Ogoni at Bomu (Dere) in 1958; since then an estimate 100 billion dollars worth of oil has been carted away from Ogoni land (Ogoni Bill Rights 1991, 61). How much of this have the people received so far? He then posited that, in return for the resources exploited Ogonis have no pipe-borne water, no electricity, very few roads, ill-equipped schools and hospitals, and no industry whatever" $(1991,6)$. What is clear is that the nature and character of the Nigerian Quota System deviate from the philosophy and spirit behind its enshrinement in the 1979, 1989, and 1999 respective constitutions as well as the past various military decrees.

There is evidence of the injustice which John Rawls' describes as "simple inequalities that are not to the benefit of all” in our quota system. No wonder in this reasoning Ken Saro-Wiwa concludes that: "These actions of the Ogoni people aim at the restoration of the inalienable rights of the Ogoni people as a distinct ethnic 
community in Nigeria, and at the establishment of a democratic Nigeria, a progressive multi-ethnic nation, a realistic society of equals, a just nation” $(1991,4)$.

\section{Conclusion}

Given the critical, logical, and objective examination of John Rawls' Difference Principle in the context of Quota System in Nigeria, this analysis reaches the following conclusions:

The Difference Principle of John Rawls' recognizes and accepts the realities of socio-economic inequalities characterizing the human community and therefore sees justice as the arrangement and/or an agreement which will lead to the improvement of the less privileged and least advantaged in the society.

It is my considered view that the philosophy behind the adoption of the Quota System is to achieve proportionate allocation of the social goods and/or gains so as to arrive at an atmosphere of social justice, fair play, and equity. But we have failed in this direction because the poor masses, the minority ethnic groups, and the women have come to experience the worst deprivation and or marginalization.

The inability to allow the theory and spirit of the Difference Principle to be reflected in the Nigerian Quota System has contributed tremendously to the patterns of hostility and antagonism, that warrant the call for fundamental reordering and/or restructuring that will benefit all ethnic groups in Nigeria. Hence, the repeated demands for National Conferences for the restructuring of the allocation of resources will be for every body's benefit.

It is also part of the conclusion of this writing that the rejection of the principle of utilitarianism, which is the greatest happiness of the greatest number, makes the Difference Principle a bourgeois and capitalist tool. This happens to be the denial of the advantages of democracy.

The Difference Principle and Quota System lay much emphasis on patronage, primordial and ethnic connections, and less emphasis on capacity and merit thereby producing inefficiency and ineffectiveness.

It is equally one's position that Quota System and federal character arrangement which lays emphasis on representation rather than on ability, skill, experience, expertise, and professionalism amounts to injustice. Nigeria has witnessed a high degree of sycophancy, amateurism, mediocrity, and low productive capacity which have landed us in a pitiable and deplorable economic, socio-political situation where the poor and least advantaged citizens are worst off.

Taking all in all, the theoretical conception of Rawls' Difference Principle as reflected philosophically is an acceptable principle of justice and a justification of the Quota System, but practically, because of man's egoism (as paramount in Nigerian leadership) and circumstantial influences of people's world-views, the Quota System has failed to enhance the benefit of every person or in particular the disadvantaged citizens in Nigeria. So, for this theory of justice to prevail, one should love his neighbors as oneself. The leadership of the nation Nigerian should exhibit the philosophy of "loving your neighbor as yourself" and jettison egoism in policies and programs.

\section{Works Cited}

Bassey, Ekpo Bassey. "Rediscovering Nigeria.” Press Statement on the Situation in the Country. Calabar: NUJ Press Centre, 1994.

Elegido, J. M. Jurisprudence. Ibadan: Spectrum Law Publishing, 2000.

Glenn, P. J. A Tour of the Summa. London: B. Hander Book Co., 1961. 
Iluyomade, B. O. et al. Cases and Material Administrative Law in Nigeria. Ile-Ife: University of Ife Press, 1980.

Nicholas, Henry. Public Administration and Public Affairs. New Jersey: Prentice Hall Inc., 1980.

"Ogoni Bill of Rights.” The Government and People of Nigeria with an Appeal to the International Community. 1991.

Omoregbe, Joseph. A Simplified History of Western Philosophy: Contemporary Philosophy. Lagos: Joja Educational Research and Publishers Ltd., 1994.

---. Introduction to Philosophical Jurisprudence. Lagos: Joja Educational Research and Publishers Ltd., 1994.

Osita, O. O. "John Rawls: John Rawls and the Quest for Social Justice.” The Great Philosophers, Vol. I. Ed. Godfrey Ozumba. Calabar: Centaur Publishers, 1996. 97-124.

Raphael, D. D. Justice and Liberty. London: Alhlona Press, 1930.

Rawls, John. A Theory of Justice. Cambridge: Harvard University Press, 1971.

Stumpf, Samuel Enoch \& Donald Abel. Elements of Philosophy: An Introduction. New York: McGraw-Hills Books Inc., 1987.

1999 Constitution of the Federal Republic of Nigeria and Fundamental Rights (Enforcement Procedure) Rules with Amendments 2011. 